J. Dairy Sci. 92:1117-1123

doi:10.3168/jds.2008-1481

(c) American Dairy Science Association, 2009.

\title{
Performance of lactating dairy cows fed ryegrass silage and corn silage with ground corn, steam-flaked corn, or hominy feed
}

\author{
K. M. Cooke, J. K. Bernard, ${ }^{1}$ and J. W. West \\ Department of Animal and Dairy Science, University of Georgia, Tifton 31793-0748
}

\begin{abstract}
Forty-eight mid-lactation Holstein cows were used in a 6-wk completely randomized block design trial with a $4 \times 3$ factorial arrangement of treatments to determine the effects of feeding different proportions of corn silage and ryegrass silage with supplemental ground corn (GC), steam-flaked corn (SFC), and hominy feed (HF) on the performance of lactating dairy cows. Forage provided $49 \%$ of the dietary dry matter in the experimental diets, which were formulated to meet National Research Council requirements. Ryegrass silage provided $100,75,50$, or $25 \%$ of the total forage dry matter, with corn silage supplying the remainder. There were no interactions between the proportion of forage provided by ryegrass silage and energy supplement. Dry matter intake and milk protein percentage decreased linearly with increasing proportions of ryegrass silage, but milk protein yield was similar among forage treatments. There were no differences among forage treatments in milk yield, milk fat percentage and yield, and energy-corrected milk yield. Dry matter intake was higher and there was a tendency for increased milk fat percentage for GC compared with SFC or HF. No other differences were observed in milk yield or composition among energy supplements. Plasma urea nitrogen and glucose concentrations were similar among treatments. Under the conditions of this trial, our results indicate that feeding a combination of corn silage and ryegrass silage is more desirable than feeding ryegrass silage alone, whereas supplementation with GC, SFC, or HF supports similar levels of milk production.
\end{abstract}

Key words: ryegrass silage, corn silage, steam-flaked corn, ground corn

\section{INTRODUCTION}

Annual ryegrass silage ( $\mathbf{R G}$ ) is a high-quality winter annual forage that when harvested in the late vegetative

Received June 24, 2008.

Accepted November 1, 2008.

${ }^{1}$ Corresponding author: jbernard@uga.edu to early boot stage of maturity provides high concentrations of rumen degradable nitrogen and highly digestible fiber to lactating dairy cows (Van Vuuren et al., 1990). Much of the protein in RG harvested at this stage of maturity is rapidly degraded in the rumen and increases urinary nitrogen excretion unless adequate amounts of rapidly fermentable carbohydrate are included in the diet. Including feeds that contain rapidly fermentable carbohydrates, such as the grain in corn silage (CS) or processing grains, improves nitrogen utilization by reducing ruminal $\mathrm{NH}_{3} \mathrm{~N}$ and urinary nitrogen excretion (Van Vuuren et al., 1993). Previous research indicates that blending CS and grass or legume silage increases yield of milk and components (Keys et al., 1984) and improves nitrogen utilization and feed costs (Dhiman and Satter, 1997). Cooke et al. (2008) reported greater DMI and yields of milk and ECM when feeding a 50:50 blend of RG:CS compared with RG alone.

In general, RG has lower starch and energy concentrations than CS. A minimal amount of starch is needed by rumen microorganisms for optimal fermentation (Cameron et al., 1991). Although CS may provide a good source of readily fermentable carbohydrate from the grain portion of the silage, additional concentrates may be beneficial to increase the total supply of readily fermentable carbohydrate to the rumen to support microbial protein synthesis and milk production when feeding a blend of RG and CS. Typically, starch is provided by ground corn (GC), which is an excellent source of readily fermentable carbohydrate. Steamflaked corn (SFC) is highly digestible in the rumen because of the denaturation of the protein matrix of the starch granule during processing. Denaturation of the matrix increases surface area and allows for greater microbial attachment and digestion of the starch granule, increasing the energy available for microbial protein synthesis and increased utilization of recycled and dietary nitrogen (Theurer et al., 1999). The net result to the animal is greater energy and microbial protein availability to support milk production. Hominy feed (HF) is a by-product of the dry-milling of corn and consists of a finely ground mixture of bran and germ. Hominy is higher in fat and fiber and lower in starch than GC (Larson et al., 1993). The objective of this 
study was to determine the effects of feeding a blend of annual ryegrass and corn silages compared with annual ryegrass silage alone with ground corn, steam-flaked corn, or hominy as a concentrate supplement on milk yield and composition in lactating dairy cows.

\section{MATERIALS AND METHODS}

Annual ryegrass was planted at the rate of $50.4 \mathrm{~kg} /$ ha in a Tifton sandy loam soil. Commercial fertilizer was applied at the rate of $54 \mathrm{~kg}$ of $\mathrm{N}, 13 \mathrm{~kg}$ of $\mathrm{P}$, and $27 \mathrm{~kg}$ of $\mathrm{K}$ per ha immediately before planting in October. An additional $57 \mathrm{~kg}$ of $\mathrm{N}$ was applied in February. The ryegrass was mown at the late vegetative stage of maturity and allowed to wilt before chopping at a 1.3-cm theoretical length of cut. A bacterial inoculate was applied as the chopped ryegrass was packed into a 2.4-m silage bag and stored until the trial began. Corn silage was produced on a Tifton sandy loam soil at a seeding rate of approximately 69,135 plants per ha. Commercial fertilizer was applied at the rate of $65 \mathrm{~kg}$ of N, $65 \mathrm{~kg}$ of $\mathrm{P}$, and $126 \mathrm{~kg}$ of $\mathrm{K}$ per ha immediately before planting plus $108 \mathrm{~kg}$ of $\mathrm{N}$ applied when the corn was approximately $60 \mathrm{~cm}$ in height. Irrigation was provided as needed to supplement natural rainfall. Corn was chopped to a theoretical chop length of 1.9 $\mathrm{cm}$ and was kernel processed with a setting of $2 \mathrm{~mm}$. A bacterial inoculate was applied at the chopper before the corn was packed in a bunker silo.

Forty-eight lactating Holstein cows averaging 139 DIM, $32.7 \mathrm{~kg} / \mathrm{d}$ of milk, and $3.5 \%$ milk fat at the beginning of the trial were used in a 6-wk randomized block design trial with a $4 \times 3$ factorial arrangement of treatments. All protocols were reviewed and approved by the University of Georgia Institute of Animal Care and Use Committee. The trial consisted of a 2-wk standardization period followed by a 4 -wk experimental period. Cows were blocked by ECM yield and assigned randomly to treatments. Treatments included 4 forages combinations (100:0, 75:25, 50:50, or $25: 75 \%$ RG blended with CS) and 3 energy supplements: GC, SFC (360 g/L), and HF. Experimental diets (Table 1) were formulated to meet NRC (2001) recommendations and contained $49.0 \%$ forage. Experimental diets were fed once daily $(0800 \mathrm{~h}$ ) behind Calan doors (American Calan, Northwood, NH) as a TMR in amounts to provide approximately $10 \%$ orts for ad libitum consumption. Amounts of each experimental diet offered and refused were recorded daily. Cows were milked twice daily at approximately 0400 and $1500 \mathrm{~h}$, and milk yield was recorded electronically (Alpro, DeLaval, Kansas City, MO).

\section{Sample Collection and Analysis}

Milk samples were collected from consecutive p.m. and a.m. milkings once each week of the trial. Milk samples were shipped to the Southeast Milk laboratory (Bellville, FL) for analyses of fat and protein concentrations using a Foss 4000 equipped with an A filter (Foss North America, Eden Prairie, MN).

Samples of each experimental diet, silages, energy supplements, and orts were collected 3 times each week. Samples were composited by week of the trial and dried at $55^{\circ} \mathrm{C}$ for $72 \mathrm{~h}$ before grinding to pass through a 1-mm screen using a Wiley mill (Arthur H. Thomas, Philadelphia, PA). The DM content of forages was determined according to Goering and Van Soest (1970) and ingredient and diet samples according to AOAC (1990). All samples were analyzed for ash (AOAC, 1990), N (Leco FP-528 Nitrogen Analyzer, St. Joseph, MI), ADF, and NDF (Van Soest et al., 1991). Starch concentrations in the energy supplements and diets were measured according to the procedure outlined by Hall (2000).

Body weights were recorded on 2 consecutive days at the end of the standardization period and wk 4 of the experimental period. To minimize variation, BW was recorded after the p.m. milking before animals had access to feed or water. Whole blood samples were collected via coccygeal venipuncture during the standardization period and during wk 4 . The blood was allowed to clot and serum was harvested by centrifugation. Samples were analyzed at the University of Georgia Veterinary Diagnostic Laboratory in Tifton for urea $\mathrm{N}$ and glucose using a Boehringer Mannheim/Hitachi 912 automated chemistry analyzer (Roche Laboratory Systems, Indianapolis, IN).

Fecal grab samples were collected from a subset of 24 cows during wk 4 of the experimental period to determine whole-tract nutrient digestibility. Samples were collected on 3 consecutive days every $12 \mathrm{~h}$ and sampling time was advanced $2 \mathrm{~h}$ each day. Samples were composited by cow and dried at $60^{\circ} \mathrm{C}$ in a forced air oven until dry. Samples were ground to pass through a 1-mm screen using a Wiley mill and analyzed for $\mathrm{DM}, \mathrm{CP}, \mathrm{ADF}$, and NDF as described previously for diets. Diet, orts, and fecal samples were analyzed for indigestible $\mathrm{ADF}$ as an internal marker (Cochran et al., 1986). Nutrient intake and digestibility coefficients were calculated using DMI measured during wk 4 and chemical analysis of diet and fecal samples collected during wk 4.

\section{Statistical Analysis}

The DMI, milk yield, and milk composition data from wk 2 to 4 were subjected to analysis of covariance 
using PROC MIXED (SAS Institute, Cary, NC). The model included the fixed effects of covariate, block, forage combination, energy supplement, week, and their interactions. Data from wk 2 of the standardization period were used as a covariate. Cow within treatment and block was included as a random effect and week was included as a repeated effect. The model for BW, urea $\mathrm{N}$, glucose, nutrient intake, and apparent digestibility data included the fixed effects of block, forage combination, energy supplement, and their interactions. Cow within treatment and block was included as a random effect. Orthogonal contrasts were included in all models to test for linear and quadratic effects of forage treatments. When significance was detected for energy supplement $(P<0.10)$, the PDIFF option was used for means separation.

\section{RESULTS AND DISCUSSION}

\section{Chemical Composition of Ingredients and TMR}

Ryegrass silage (Table 2) had lower concentrations of DM than normally desired because of poor drying conditions at harvest that prevented the desired amount of wilting. Concentrations of ash were greater and NDF concentrations lower than normal (NRC, 2001). The greater ash content is related to contamination by the sandy soils in which the RG was grown during harvest and is consistent with previous analysis of RG grown at this location. The chemical composition of GC and SFC were similar yet slightly higher in NDF concentration than normal for both ingredients (NRC, 2001).

The composition of the experimental diets is presented in Table 3. The DM content of experimental diets increased and ash decreased as CS replaced RG because of greater DM and lower ash concentrations of CS. Although diets were formulated to be isonitrogenous, the 25:75 RG:CS plus SFC diet was numerically lower in $\mathrm{CP}$ concentrations compared with other diets. Concentrations of NDF were slightly higher for 100:0 RG:CS plus HF and lower for 25:75 RG:CS plus GC compared with all other experimental diets but all levels were adequate to maintain rumen function. Similarly, concentrations of ADF were greater for 100:0 RG:CS plus $\mathrm{HF}$ and lower for 25:75 RG:CS plus GC diets. Starch concentrations were highest for diets containing $75 \%$ CS regardless of concentrate supplement because of the greater starch concentration of CS compared with RG. Diets containing 100\% RG supplemented with HF contained significantly less starch $(16.0 \%$ of DM) than all other diets (average $23.5 \%$ of DM). Concentrations of NFC were greater for diets containing CS compared with RG because of the grain portion of CS. 
Table 2. Composition of corn silage (CS), ryegrass silage (RG), ground corn (GC), steam-flaked corn (SFC), and hominy (HF) ${ }^{1}$

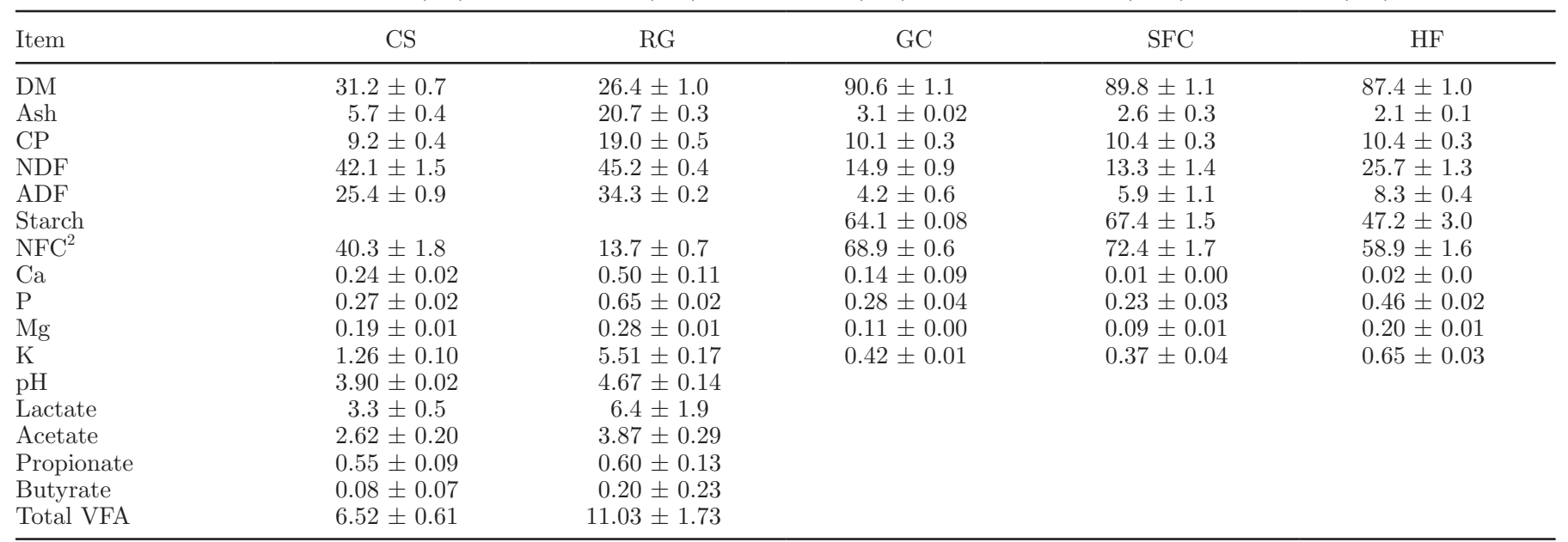

${ }^{1}$ Mean and standard deviation of 4 samples. All values except for DM are expressed as a percentage of DM.

${ }^{2} \mathrm{NFC}$ was calculated using actual values for ash, CP, and NDF and NRC (2001) values for fat.

\section{Production Response}

The DMI, milk yield and composition responses for the trial are presented in Table 4 . A linear decrease $(P$ $=0.05)$ in DMI was observed as RG replaced CS. No differences in DMI were observed when ryegrass silage replaced $0,35,65$, or $100 \%$ of the DM provided by CS in a previous trial (Bernard et al., 2002). Burke et al. (2007) reported increased DMI when CS replaced $33 \%$ of the forage DM supplied by perennial ryegrass silage compared with diets based on $100 \%$ perennial ryegrass silage. Cooke et al. (2008) reported greater DMI for cows consuming a 50:50 blend of RG:CS compared with diets based on RG alone (22.8 vs. $19.4 \mathrm{~kg} / \mathrm{d})$. Others (Bernard et al., 2002) have noted no difference in DMI among cows fed different concentrations of RG and CS blends. In the current study dietary NDF concentrations decreased slightly as CS replaced RG and averaged $34.7,33.8,32.8$, and $30.7 \%$ of DM for 100:0, 75:25, 50:50, and 25:75 RG:CS, respectively. Average NDF intake was $1.18 \%$ of BW for all treatments and was similar for all treatments. The DMI was highest $(P$ $=0.02)$ for cows consuming GC $(22.3 \mathrm{~kg} / \mathrm{d})$ compared with HF $(21.5 \mathrm{~kg} / \mathrm{d})$ and SFC $(21.0 \mathrm{~kg} / \mathrm{d})$. This is consistent with previous research in our lab in which DMI was lower for cows consuming diets supplemented with SFC compared with GC (Bernard et al., 2004).

Yields of milk, milk fat, milk protein, and ECM were similar among forage treatments regardless of RG:CS ratio, and average milk yield was $31.3 \mathrm{~kg} / \mathrm{d}$. Milk protein percentage $(P=0.01)$ was greatest for the $25: 75$ RG:CS diet and decreased as the proportion of RG increased in the diet. Diets containing corn silage had greater starch concentrations and would presumably provide more fermentable energy for microbial protein synthesis than RG. The NRC (2001) model predicted a total and bacterial MP supply of 5.8 and $2.7 ; 5.6$ and 2.6; 5.4 and 2.4 ; and 4.9 and $2.4 \mathrm{~kg} / \mathrm{d}$ for $25: 75,50: 50$, 75:25, and 100:0 RG:CS, respectively, averaged across energy supplements.

Energy supplement had no effect on milk yield or yields of milk fat or protein. There was a weak tendency $(P=0.13)$ for increased milk fat percentage in cows consuming GC versus SFC or HF. These results are in agreement with previous research (Cooke et al., 2008). However, Dhiman et al. (2002) reported that milk fat percentage was reduced by $7 \%$, on average, when cows were fed SFC compared with finely ground corn. Efficiency of milk production, defined as ECM/ DMI, was similar among all treatments, regardless of forage or concentrate source.

Initial BW of cows was similar among treatments and averaged $610 \mathrm{~kg}$. All cows experienced positive BW gain during the trial as would be expected for mid-lactation cows. There was a linear decrease $(P=0.04)$ in total BW gain over the 4-wk trial as the proportion of RG in the diet increased from 25 to $100 \% ; 18.0,16.5,10.1$, and $6.7 \mathrm{~kg}$ for 25:75, 50:50, 75:25, and 100:0 RG:CS, respectively. No differences in total BW gain over the 4 -wk trial were observed among energy supplements. Serum urea nitrogen and glucose concentrations were also similar among treatments (Table 4).

\section{Nutrient Intake and Digestibility}

Nutrient intake and digestibility as measured during wk 4 of the trial are presented in Table 5. No differences were observed in nutrient intake among forage or 
Table 3. Chemical composition of experimental diets (\% of DM) varying in the proportion of ryegrass silage (RG) and corn silage (CS) and supplemented with ground corn (GC), steam-flaked corn (SFC), or hominy $(\mathrm{HF})^{1}$

\begin{tabular}{|c|c|c|c|c|c|c|c|c|c|c|c|c|}
\hline \multirow[b]{2}{*}{ Item } & \multicolumn{3}{|c|}{$\mathrm{RG}: \mathrm{CS}=100: 0$} & \multicolumn{3}{|c|}{$\mathrm{RG}: \mathrm{CS}=75: 25$} & \multicolumn{3}{|c|}{$\mathrm{RG}: \mathrm{CS}=50: 50$} & \multicolumn{3}{|c|}{$\mathrm{RG}: \mathrm{CS}=25: 75$} \\
\hline & $\mathrm{GC}$ & $\mathrm{SFC}$ & $\mathrm{HF}$ & $\mathrm{GC}$ & SFC & $\mathrm{HF}$ & $\mathrm{GC}$ & SFC & $\mathrm{HF}$ & $\mathrm{GC}$ & $\mathrm{SFC}$ & $\mathrm{HF}$ \\
\hline $\mathrm{DM}, \%$ & 40.7 & 41.1 & 41.9 & 42.9 & 42.0 & 42.8 & 43.9 & 42.6 & 43.6 & 45.4 & 45.1 & 44.8 \\
\hline Ash & 14.0 & 13.3 & 13.8 & 12.3 & 13.1 & 12.8 & 10.8 & 11.5 & 11.4 & 8.4 & 9.3 & 9.3 \\
\hline $\mathrm{CP}$ & 18.0 & 17.9 & 18.4 & 18.8 & 18.3 & 18.4 & 18.3 & 18.7 & 19.0 & 18.7 & 17.0 & 18.1 \\
\hline $\mathrm{RDP}^{2}$ & 12.4 & 11.6 & 13.1 & 11.9 & 11.1 & 12.5 & 11.4 & 10.6 & 11.9 & 10.7 & 10.1 & 11.4 \\
\hline $\mathrm{RUP}^{2}$ & 6.1 & 7.1 & 5.5 & 6.5 & 7.5 & 6.0 & 6.8 & 7.7 & 6.3 & 7.1 & 7.8 & 6.6 \\
\hline NDF & 33.4 & 33.8 & 37.0 & 34.0 & 32.6 & 34.8 & 32.1 & 32.7 & 33.7 & 29.6 & 31.1 & 31.4 \\
\hline $\mathrm{ADF}$ & 22.4 & 22.2 & 25.5 & 24.3 & 22.7 & 24.1 & 21.7 & 22.0 & 22.6 & 18.6 & 19.6 & 19.7 \\
\hline Starch & 20.1 & 20.4 & 16.0 & 21.9 & 22.7 & 19.8 & 22.8 & 24.5 & 21.6 & 28.9 & 29.0 & 27.0 \\
\hline $\mathrm{NFC}^{2}$ & 33.7 & 34.4 & 30.5 & 35.7 & 36.3 & 32.7 & 37.7 & 38.2 & 34.9 & 39.9 & 40.4 & 37.3 \\
\hline $\mathrm{NE}_{\mathrm{L}},{ }^{2} \mathrm{Mcal} / \mathrm{kg}$ & 1.57 & 1.61 & 1.57 & 1.59 & 1.61 & 1.57 & 1.61 & 1.63 & 1.59 & 1.61 & 1.65 & 1.63 \\
\hline
\end{tabular}

${ }^{1}$ Mean of 4 samples.

${ }^{2}$ Values calculated using NRC (2001) model and chemical values reported in Table 2.

Table 4. Dry matter intake, milk yield and composition, and serum metabolite concentrations of lactating Holstein cow fed diets differing in proportions of corn silage (CS) and ryegrass silage (RG) supplemented with ground corn (GC), steam-flaked corn (SFC), or hominy (HF)

\begin{tabular}{|c|c|c|c|c|c|c|c|c|c|c|c|}
\hline \multirow[b]{2}{*}{ Item } & \multicolumn{4}{|c|}{ Proportion of RG:CS } & \multirow[b]{2}{*}{ SE } & \multirow[b]{2}{*}{$P$-value } & \multicolumn{3}{|c|}{ Supplemental grain } & \multirow[b]{2}{*}{$\mathrm{SE}$} & \multirow[b]{2}{*}{$P$-value } \\
\hline & $25: 75$ & $50: 50$ & $75: 25$ & 100:0 & & & GC & $\mathrm{SFC}$ & $\mathrm{HF}$ & & \\
\hline $\mathrm{DMI}, \mathrm{kg} / \mathrm{d}$ & 22.1 & 21.7 & 21.7 & 20.7 & 0.34 & $0.05^{\mathrm{a}}$ & $22.3^{\mathrm{b}}$ & $21.0^{\mathrm{c}}$ & $21.5^{\mathrm{bc}}$ & 0.3 & 0.02 \\
\hline Milk, $\mathrm{kg} / \mathrm{d}$ & 31.6 & 30.8 & 32.3 & 30.3 & 0.8 & 0.21 & 31.6 & 30.8 & 31.1 & 0.7 & 0.72 \\
\hline Fat, $\%$ & 3.90 & 3.63 & 3.91 & 4.01 & 0.14 & 0.30 & 4.07 & 3.82 & 3.70 & 0.13 & 0.13 \\
\hline Fat, $\mathrm{kg} / \mathrm{d}$ & 1.22 & 1.12 & 1.23 & 1.24 & 0.08 & 0.69 & 1.27 & 1.21 & 1.12 & 0.07 & 0.30 \\
\hline Protein, \% & 3.00 & 2.92 & 2.85 & 2.85 & 0.03 & 0.01 & 2.89 & 2.91 & 2.91 & 0.03 & 0.92 \\
\hline Protein, $\mathrm{kg} / \mathrm{d}$ & 0.93 & 0.88 & 0.90 & 0.84 & 0.03 & 0.25 & 0.89 & 0.88 & 0.89 & 0.02 & 0.96 \\
\hline $\mathrm{ECM},{ }^{1} \mathrm{~kg} / \mathrm{d}$ & 32.7 & 30.3 & 32.6 & 31.7 & 1.4 & 0.61 & 33.0 & 32.0 & 30.5 & 1.1 & 0.34 \\
\hline $\mathrm{EFF}^{2}$ & 1.46 & 1.39 & 1.51 & 1.51 & 0.06 & 0.46 & 1.48 & 1.52 & 1.42 & 0.05 & 0.43 \\
\hline Urea N, mg/dL & 14.75 & 12.33 & 14.17 & 13.83 & 0.73 & 0.13 & 13.69 & 13.13 & 14.50 & 0.63 & 0.32 \\
\hline Glucose, $\mathrm{mg} / \mathrm{dL}$ & 68.00 & 67.83 & 67.42 & 68.17 & 1.51 & 0.99 & 68.38 & 68.63 & 66.63 & 1.31 & 0.52 \\
\hline
\end{tabular}

$\lesssim \quad{ }^{a}$ Linear decrease in DMI as the proportion of RG increased.

b,c Means within a row with different superscripts differ $(P<0.05)$.

乙 $\quad{ }^{1} \mathrm{ECM}=(0.327 \times \mathrm{kg}$ of milk $)+(12.95 \times \mathrm{kg}$ of fat $)+(7.65 \times \mathrm{kg}$ of protein $)$

${ }^{2} \mathrm{EFF}=$ efficiency of converting DMI to ECM. 


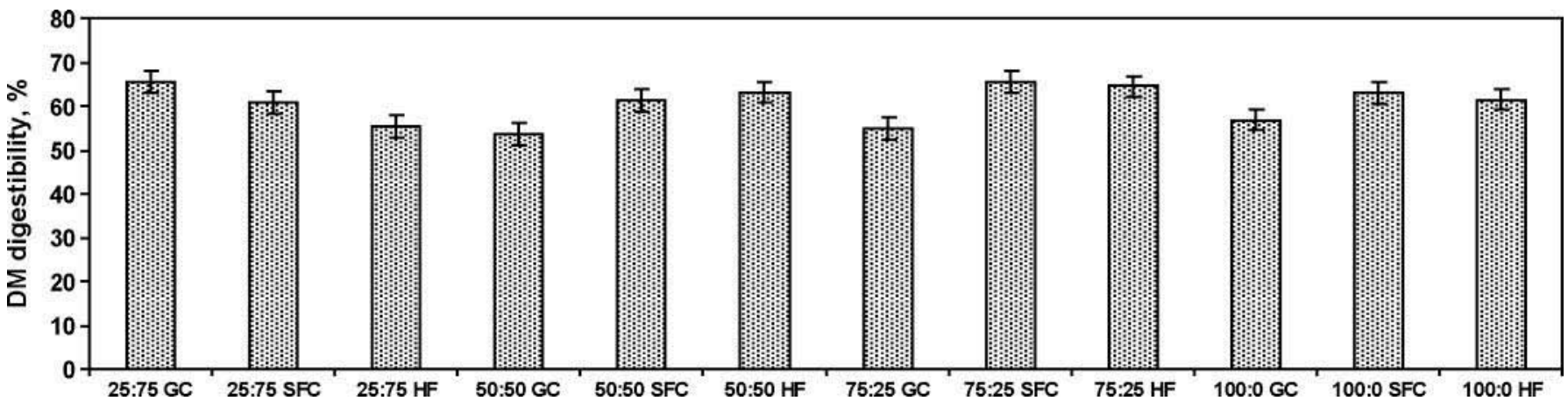

Figure 1. Interaction of forage and grain supplement $(P=0.04, \mathrm{SE}=2.5)$ for apparent DM digestibility of lactating Holstein cows fed diets differing in proportions of ryegrass and corn silage (25:75, 50:50, 75:25 or 100:0, respectively) and supplemented with ground corn (GC), steam-flaked corn (SFC), or hominy (HF).

energy supplement source during wk 4 of the trial when nutrient digestibility was measured. The DMI from wk 4 is similar to the DMI observed for the entire trial. An interaction of forage combination and energy supplement was observed for DM digestibility $(P=0.04)$. As the proportion of RG in the diet increased from 25 to $75 \%$, DM digestibility improved when diets were supplemented with either SFC or HF, whereas DM digestibility for diets supplemented with GC was highest for the 25:75 RG:CS diet and decreased as the proportion of RG increased (Figure 1). The digestibility of DM was highest $(P=0.04)$ when diets were supplemented with SFC compared with GC.

As the concentration of RG increased in the diet, $\operatorname{NDF}(P=0.03)$ and $\operatorname{ADF}(P=0.006)$ digestibility increased linearly. Cooke et al. (2008) observed a decrease in apparent NDF and ADF digestibility when feeding a 50:50 blend of RG:CS compared with feeding RG as the sole forage. Hoffman et al. (1998) reported decreased passage rates and increased rumen retention times when cows were fed diets based on perennial ryegrass silage compared with alfalfa silage. Others (Broderick et al., 2002) have reported similar responses in nutrient digestibility when comparing perennial ryegrass with alfalfa.

Whole-tract digestibility of DM $(P=0.04)$ and $\mathrm{OM}$ $(P=0.03)$ was greatest for SFC compared with $\mathrm{HF}$ and GC. Previous research (Cooke et al., 2008) reported increased digestibility of $\mathrm{DM}$ and $\mathrm{OM}$ when diets were supplemented with SFC compared with GC. Others (Yu et al., 1998; Bernard et al., 2004) did not observe any differences in DM digestibility between SFC and GC. Digestibility of NDF $(P=0.06)$ was greater for diets supplemented with GC compared with HF. This is in contrast to previous research by Larson et al. (1993) in which NDF digestibility increased as HF replaced

Table 5. Nutrient intake and digestibility of lactating Holstein cow fed diets differing in proportions of corn silage (CS) and ryegrass silage (RG) supplemented with ground corn (GC), steam-flaked corn (SFC) or hominy (HF) ${ }^{1}$

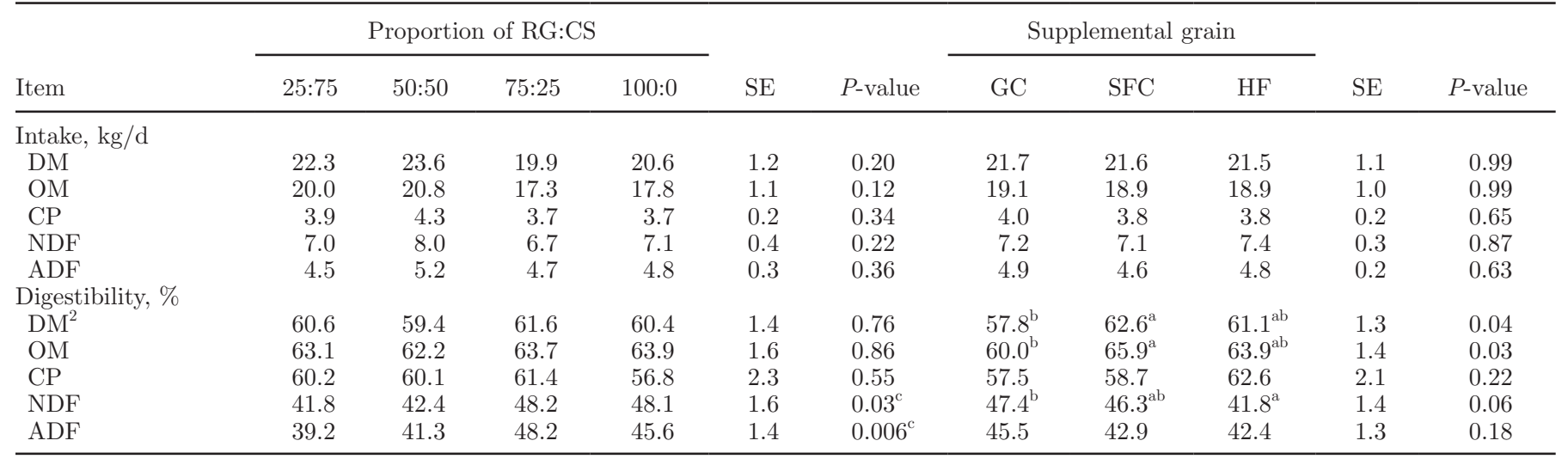

\footnotetext{
${ }^{\mathrm{a}, \mathrm{b}}$ Means with unlike superscripts differ $(P<0.05)$.

${ }^{c}$ Linear response to increasing amounts of ryegrass silage.

${ }^{1}$ Digestibility data collected during wk 4 of the trial.

${ }^{2}$ There was an interaction between forage proportion and energy supplement $(P=0.04)$.
} 
GC in the diet of finishing lambs. The starch content of GC was approximately $20 \%$ greater compared with $\mathrm{HF}$, whereas HF contained almost $92 \%$ more NDF than GC. Larson et al. (1993) attributed the greater fiber digestibility of HF to reduced negative associative effects of starch digestion on fiber digestion in the rumen.

\section{CONCLUSIONS}

Results of this study indicate that feeding a combination of $\mathrm{CS}$ and $\mathrm{RG}$ is more desirable than feeding ryegrass silage. Milk protein percentage was improved when diets contained proportionally more CS than RG. Diets containing more RG than CS had improved digestibility of ADF and NDF, but this did not translate into improved performance or BW gain. Supplementation with GC, SFC, or HF supported similar performance across all forage combinations. However, SFC and HF appear to support greater digestibility of DM compared with GC as the proportion of RG in the diet increases. These results suggest that diets for mid-lactation can be formulated with various combinations of CS and RG and supplemented with GC, SFC, or HF without affecting production.

\section{ACKNOWLEDGMENTS}

Partial funding for this project was provided by the Southeast Milk Checkoff. The authors extend their appreciation to Harmon Tawzer and the farm crew (UGA, Tifton) for producing and harvesting the forages required for the study, to Sue Trammell, Heath Cross, and the dairy staff (UGA, Tifton) for providing animal care and daily oversight of the trial, and to Melissa Tawzer (UGA, Tifton) for assistance with chemical analyses.

\section{REFERENCES}

AOAC. 1990. Official Methods of Analysis. 15th ed. AOAC, Washington, DC.

Bernard, J. K., P. T. Chandler, J. W. West, A. H. Parks, H. A. Amos, M. A. Froetschel, and D. S. Trammell. 2004. Effect of supplemental L-lysine- $\mathrm{HCl}$ and corn source on rumen fermentation and amino acid flow to the small intestine. J. Dairy Sci. 87:399-405.

Bernard, J. K., J. W. West, and D. S. Trammell. 2002. Effect of replacing corn silage with annual ryegrass silage on nutrient digestibility, intake, and milk yield for lactating dairy cows. J. Dairy Sci. 85:2277-2282.
Broderick, G. A., R. G. Koegel, R. P. Walgenbach, and T. J. Kraus. 2002. Ryegrass or alfalfa silage as the dietary forage for lactating dairy cows. J. Dairy Sci. 85:1894-1901.

Burke, F., J. J. Murphy, M. A. O'Donovan, F. P. O'Mara, S. Kavanagh, and F. J. Mulligan. 2007. Comparative evaluation of alternative forages to grass silage in the diet of early lactation dairy cows. J. Dairy Sci. 90:908-917.

Cameron, M. R., T. H. Klusmeyer, G. L. Lynch, J. H. Clark, and D. R. Nelson. 1991. Effects of urea and starch on rumen fermentation, nutrient passage to the duodenum, and performance of cows. J. Dairy Sci. 74:1321-1336.

Cochran, R. C., D. C. Adams, J. D. Wallace, and M. L. Galyean. 1986. Predicting digestibility of difference diets with internal markers: Evaluation of four potential markers. J. Anim. Sci. 63:14761483.

Cooke, K. M., J. K. Bernard, and J. W. West. 2008. Performance of lactating dairy cows fed annual ryegrass silage and corn silage with steam-flaked or ground corn. J. Dairy Sci. 91:2417-2422.

Dhiman, T. R., and L. D. Satter. 1997. Yield response of dairy cows fed different proportions of alfalfa silage and corn silage. J. Dairy Sci. 80:2069-2082.

Dhiman, T. R., M. S. Zaman, I. S. MacQueen, and R. L. Boman. 2002. Influence of corn processing and frequency of feeding on cow performance. J. Dairy Sci. 85:217-226.

Goering, H. K., and P. J. Van Soest. 1970. Forage Fiber Analysis. USDA Agricultural Research Service. Handbook number 379. U.S. Department of Agriculture. Superintendent of Documents, US Government Printing Office, Washington, DC.

Hall, M. B. 2000. Neutral detergent-soluble carbohydrates-Nutritional relevance and analysis: A laboratory manual. Univ. Florida Ext. Bull. 339, Gainesville.

Hoffman, P. C., D. K. Combs, and M. D. Casler. 1998. Performance of lactating dairy cows fed alfalfa silage or perennial ryegrass silage. J. Dairy Sci. 81:162-168.

Keys, J. E., R. E. Pearson, and R. H. Miller. 1984. Effect of ratio of corn silage to grass-legume silage with high concentrate during dry period on milk production and health of dairy cows. J. Dairy Sci. $67: 307-312$.

Larson, E. M., R. A. Stock, T. J. Klopfenstein, M. H. Sindt, and D. H. Shain. 1993. Energy value of hominy feed for finishing ruminants. J. Anim. Sci. 71:1092-1099.

National Research Council. 2001. Nutrient Requirements of Dairy Cattle. 7th rev. ed. Natl. Acad. Press, Washington, DC

Theurer, C. B., J. T. Huber, A. Delgado-Elorduy, and R. Wanderley. 1999. Invited review: Summary of steam-flaked corn or sorghum grain for lactating dairy cows. J. Dairy Sci. 82:1950-1959.

Van Soest, P. J., J. B. Robertson, and B. A. Lewis. 1991. Methods for dietary fiber, neutral detergent fiber, and nonstarch polysaccharides in relation to animal production. J. Dairy Sci. 74:3583-3597.

Van Vuuren, A. M., S. Tamminga, and R. S. Ketelaar. 1990. Ruminal availability of nitrogen and carbohydrates from fresh and preserved herbage in dairy cows. Neth. J. Agric. Sci. 38:499-512.

Van Vuuren, A. M., C. J. Van Der Kielen, H. Valk, and H. De Visser. 1993. Effects of partial replacement of ryegrass by low protein feeds on rumen fermentation and nitrogen loss by dairy cows. J. Dairy Sci. 76:2982-2993.

Yu, P., J. T. Huber, F. A. P. Santos, J. M. Simas, and C. B. Theurer. 1998. Effects of ground, steam-flaked, and steam-rolled corn grains on performance of lactating cows. J. Dairy Sci. 81:777-783. 